\title{
Perception of Verbal Communication of the Teacher in the Classroom by Pupils of Different Genders (Females-Males)
}

\author{
Dr. Gentjana Panxhi \\ Lecturer at the Faculty of Education, "Aleksandër Moisiu" Durrës University \\ Email: genta_panxhi@yahoo.com
}

\section{Doi:10.5901/ajis.2016.v5n3s1p295}

\section{Abstract}

\begin{abstract}
Verbal communication which mainly provided through the word is a form of communication which is realized not only in life but also in the teaching process. This kind of communication during the teaching process should not only serve to simplify reality, for transmission and organization of knowledge, to remind the experience of the past, but should also aim at the creation of a favorable climate in the classroom, as well as encouraging pupils for the higher results cognitive and affective. But equally is perceived, and has a difference in his meaning by the pupils of different genders (females-males), and whether this affects the school performance of these students? These and other aspects of communication are the main object of this research. Through this study aims to explore how are perceived some aspects of verbal communication to the teachers, to the pupils of different genders, and to identify the correlation between the perception of verbal communication of the teacher and school performance of students. To achieve the objectives of the paper were conducted on the ground survey at middle school, asking at the same time students of different genders, ages, classes and different levels, distributed in four cities of Albania.
\end{abstract}

Keywords: verbal communication, pupils, teacher, teaching process, performance, gender.

\section{Introduction}

Apart from the approach as a key means in the process of socialization and building inter-personal relations, communication also serves as one of the most crucial elements of learning, not to mention that the learning process may be regarded as a continuous flow of communication Exchange by which not only knowledge and ideas are transmitted, but also as a flow of communication relations. Accordingly, both in the concept of classical learning and modern pedagogy, the teacher-1-student communication relations are treated as an extension of teacher-student relations over space and time. Furthermore, two main forms of communication are defined, namely the verbal communication (by words, listening, writing and reading) and non-verbal communication (any kind of communication apart from the verbal one). This type of communication is displayed not only in daily life, but is also reflected in the learning-educational process.

Multiple definitions on communication are encountered over time. Researchers of the field of communication introduce various definitions, and sometimes concepts that contradict each other. What we notice, is that we cannot find a definition reconciling the theoreticians of communication sciences with a unique view on communication. By the term "communication", Shannon and Weaver implied all procedures through which one mind influences another (Shannon and Weaver, 1949: 95).

Further, according to Hoben, communication is the verbal exchange of a thought or idea (Hoben, J., 1954: 76).

For Watzlawick $(1967,2008)$, communication is "a process of interaction between various communicating persons".

\section{Methodology of Study}

In order to achieve the objectives of this study, to deliver the opinion of students about the teacher's verbal communication, field questionnaires were realized, specifically from high school students in the four largest cities of

${ }^{1}$ The term "teacher" implies both genders. This is also stressed by the fact that in all educational cycles the teachers are higher in number. 
Albania, where the number of public and non-public schools is higher, including in the questionnaire at the same time the students of all levels (classes 10-12).

Over 1050 students are questioned via questionnaire. The participating respondents were randomly chosen being of different genders and ages. They studied in classes of different levels, thus making the sample more representative.

The sampling method was selected in such a way as to provide comprehensive data. The study was extended to the cities with the largest number of public and non-public schools, respectively of the students who carry out didacticeducational activities therein. They are: Shkodra in the Northern Albania; Durrës and Tirana in the Middle Albania and Vlora in the Southern Albania (table 1).

Table 1. Distribution of students by city

\begin{tabular}{|c|c|c|}
\hline City & Frequency & Percentage \\
\hline Durrës & 209 & 19.9 \\
\hline Shkodër & 166 & 15.8 \\
\hline Tiranë & 545 & 51.9 \\
\hline Vlorë & 130 & 12.4 \\
\hline Total & 1050 & 100.0 \\
\hline
\end{tabular}

Regarding the classification by gender, the following graph shows that $55.5 \%$ of the students who have attended the study are females and the remainder, namely $44.5 \%$ are males, knowing that the ratio of females to males at national leve lis generally higher.

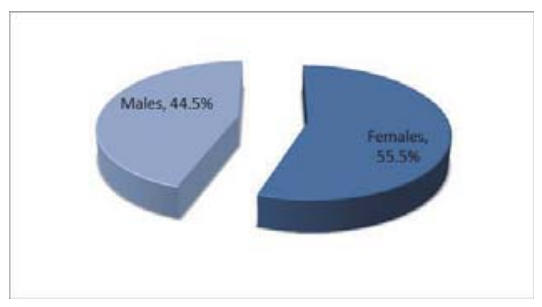

Graph 1. Participation of students by gender

The interviewees have an average age of 16.5 years old, while the minimum age of the interviewees is 15 years old and the maximum age is 20 years old. The study has also included professional schools with a 4-year time span.

\section{Data Analysis}

The students are also questioned about their educational level (academic results achieved) and the answers are listed as follows: half of them, $50.3 \%$ have declared they have an average academic performance, followed by $28.5 \%$ of the students, who stated that their educational level is higher and the remainder had a very high level of $12.4 \%$. However, data show that also in $7.4 \%$ of the cases, their level is poor and for $1.4 \%$ the academic level is very poor (graph 2).

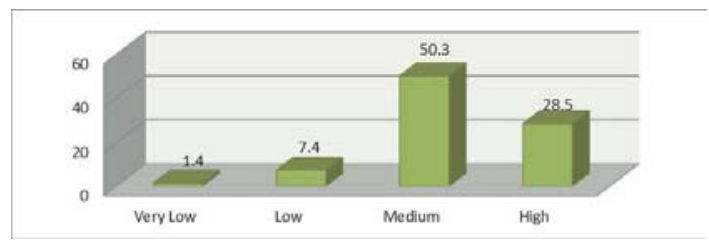

Graph 2. The evaluation of the learning level

Further, by analyzing the level and results with gender, we observe that boys generally have a poor or very poor 
academic performance, respectively by $74.7 \%$ and $86.7 \%$. Regarding the average level, $52.6 \%$ of the students who have declared of having an average level of results are females and the remainder of $47.4 \%$ are males. Also, among the students who state of having a high level, 173 or $69.8 \%$ are females and the remainder of 75 students or $32.2 \%$ are males. The same trend is also observed with the very high level of results, where again females prevail with $67.2 \%$ over males with $32.8 \%$ (table 2).

Table 2. Analysis between gender and the assessment for the educational level of the students

\begin{tabular}{|c|c|c|c|c|c|c|c|c|c|c|c|c|}
\hline \multirow{2}{*}{ Gender } & \multicolumn{9}{|c|}{ How do you evaluate your level of education? } & \\
\cline { 2 - 15 } & Very low & $\%$ & Low & $\%$ & Average & $\%$ & High & $\%$ & Very high & $\%$ & Total & $\%$ \\
\hline Female & 2 & $.3 \%$ & 24 & $4.1 \%$ & 292 & $50.1 \%$ & 173 & $29.7 \%$ & 92 & $15.8 \%$ & 583 & $100.0 \%$ \\
\hline$\%$ & $13.3 \%$ & & $25.3 \%$ & & $52.6 \%$ & & $69.8 \%$ & & $67.2 \%$ & & $55.5 \%$ & \\
\hline Male & 13 & $2.8 \%$ & 71 & $15.2 \%$ & 263 & $56.3 \%$ & 75 & $16.1 \%$ & 45 & $9.6 \%$ & 467 & $100.0 \%$ \\
\hline$\%$ & $86.7 \%$ & & $74.7 \%$ & & $47.4 \%$ & & $30.2 \%$ & & $32.8 \%$ & & $44.5 \%$ & \\
\hline Total & 15 & $1.4 \%$ & 95 & $9.0 \%$ & 555 & $52.9 \%$ & 248 & $23.6 \%$ & 137 & $13.0 \%$ & 1050 & $100.0 \%$ \\
\hline$\%$ & $100.0 \%$ & & $100.0 \%$ & & $100.0 \%$ & & $100.0 \%$ & & $100.0 \%$ & & $100.0 \%$ & \\
\hline
\end{tabular}

Referring to their educational level, this is also reflected in the descriptive statistics regarding their average grade. Thus, according to data of the following table, it is observed that the average declared sample grade is 8.1, the lowest grade is 4.5 and the highest grade is 10 (table 3 ).

Table 3. Descriptive statistics for the average grade of the students

\begin{tabular}{|c|c|c|c|c|c|c|}
\hline & Number & Minimum & Maximum & Average grade & Standard deviation & Variance \\
\hline Your grade average & 1050 & 4.5 & 10.0 & 8.1 & 1.19 & 1.41 \\
\hline
\end{tabular}

Regarding one of the questions on verbal communication, the respondents answered as follows: Question - When the teacher uses stimulating words during explanation, do you manage to be more motivated in the lesson?, 40.3\% agreed and $25.7 \%$ stated they fully agreed, where more than half or $51.9 \%$ of those who agreed, are females and $40.9 \%$ are males. Further, $23.5 \%$ of them stated they did not agree or did not agree at all and mostly the males are those who provided such answers, with $60.3 \%$ and $51.5 \%$, respectively did not agree and partly agreed.

The rest of them adopted an impartial position, without preferring to see it as a motivating factor for them. By analyzing this phenomenon in connection with the academic performance, we observe that $68.6 \%$ of the students with high results agreed or fully agreed. The same are also the students with high results, while $16.8 \%$ of the students with poor results partly agreed and the same number stated they did not agree at all with the fact that use of stimulating words during explanation motivates them more. $20 \%$ of those students with very poor results stated they did not agree at all and $26.7 \%$ thereof partly agreed, but there are also students, who despite the poor academic performance, reconcile with the fact that stimulating words serve as a good motivation for them. This category represents $53.3 \%$, while the rest are impartial in their answers.

As regards the assumption- When the teacher does not select proper words for the lesson, you fail to understand it, $62.2 \%$ of the students stated they agreed or fully agreed.

The females express their consent in more than half of these answers, with $57.7 \%$ who agreed and fully agreed in $60.9 \%$, while males respectively by $42.3 \%$ and $39.1 \%$. $8.8 \%$ are impartial and the rest did not agree with the fact that choice of words by the teachers is the solution to better understand the lesson.

As regards the assumption: - When the teacher speaks dialect language, the lesson becomes harder for them to understand, answers have shown this is true for $56.4 \%$ of the students, namely the communication by the teacher in dialect language renders somewhat more difficult the understanding of lesson for them. $11 \%$ of the interviewed students have adopted an impartial position and for $31.6 \%$, namely around $1 / 3$ thereof, communication with them in dialect language does not represent a concern ( $46.1 \%$ of those, who are not disturbed by dialect language, are females). Furthermore, there are more females who partly agreed, with $55.1 \%$ and males with $44.9 \%$. This also occurs because in large cities, mostly in Tiranë, the students come from the area where the same dialect is spoken and dot not represent an issue of concern.

Regarding the assumption: - When the teacher continuously raises the voice (screams) in the lesson, then I can hardly learn this subject, for $21.4 \%$ of the total number of students, this does not represent a concern, especially for 
females with $55.1 \%$ and for males with $44.9 \%$. Mostly, there are students who have low academic results or learning by this method of communication, while for most of them, with around $67.1 \%$, raised voice or screaming during lessons by the teacher constitute a concern, where female students respectively agreed and fully agreed with this fact in $63.1 \%$ and $53.8 \%$, because according to them, this makes the subject more difficult. Following the pedagogical practice and various studies of this field, it is clearly highlighted that proper communication is often the key of success in the teacher-student relations. As it is often heard, the students do not learn the subject merely because of the mode of behavior of the relevant teacher.

When questioned about the fact: - The words chosen by the teacher during the lesson are not very important, what matters is to give them meaning, in $48 \%$ of cases the students agreed or fully agreed, respectively the females amounted to $52.8 \%$ and $47 \%$. Male students who represented $47.2 \%$ agreed and fully agreed, a little more than females, thus accounting for $53 \%$ and $46 \%$ did not agree, namely they did not agree, where $59.3 \%$ are female students and $40.7 \%$ males.

The assumption: - When the teacher is too spared in words during explanation, I fail to fully understand the lesson, this is true for $62.8 \%$ of the interrogated students, namely they agreed, especially the students who are attentive and carefully follow the lesson while explaining new knowledge or special lesson-related issues. Even $59.2 \%$ and $61.8 \%$ of those who respectively agreed or fully agreed are females and the rest are males, respectively with $40.8 \%$ and $38.2 \%$. For $24.3 \%$ the spared words in lessons do not represent an issue of concern, where males occupy the largest percentage, respectively $54.7 \%$ did not agree at all and $51.5 \%$ partly agreed, while the rest of them, $12.8 \%$ have maintained an unbiased position.

Table no. 4 propvides a summary of the students' answers on verbal communication.

Table 4. Evaluation about verbal communication

\begin{tabular}{|c|c|c|c|c|c|c|c|c|c|c|c|c|}
\hline \multirow[b]{2}{*}{ Communication } & \multicolumn{12}{|c|}{ Evaluation about verbal communication } \\
\hline & $\begin{array}{l}\text { Strongly } \\
\text { disagree }\end{array}$ & $\%$ & $\begin{array}{l}\text { Partly } \\
\text { agree }\end{array}$ & $\%$ & Neutral & $\%$ & Agreed & $\%$ & $\begin{array}{l}\text { Strongly } \\
\text { agree }\end{array}$ & $\%$ & Total & $\%$ \\
\hline $\begin{array}{l}\text { Do you agree with the fact that when the teacher } \\
\text { uses encouraging words during explanation, you } \\
\text { manage to be more motivated in lessons? }\end{array}$ & 78 & 7.4 & 169 & 16.1 & 110 & 10.5 & 423 & 40.3 & 270 & 25.7 & & $\mid 100.0$ \\
\hline $\begin{array}{l}\text { To what extent do you agree with the fact that } \\
\text { when the teacher does not choose proper words } \\
\text { for the lesson, you fail to understand? }\end{array}$ & 147 & 14.0 & 157 & 15.0 & 92 & 8.8 & 265 & 25.2 & 389 & 37.0 & 1050 & 100.0 \\
\hline $\begin{array}{l}\text { When the teacher speaks with dialect, the lesson } \\
\text { becomes more difficult for me to understand. }\end{array}$ & 165 & 15.7 & 167 & 15.9 & 115 & 11.0 & 246 & 23.4 & 357 & 34.0 & 1050 & 100.0 \\
\hline $\begin{array}{l}\text { The words chosen by the teacher during lesson } \\
\text { do not matter much, what matters is to give them } \\
\text { meaning. }\end{array}$ & 258 & 24.6 & 224 & 21.3 & 169 & 16.1 & 216 & 20.6 & 183 & 17.4 & 1050 & 100.0 \\
\hline $\begin{array}{l}\text { When the teacher is too spared in words during } \\
\text { explanation, I fail to fully understand the lesson. }\end{array}$ & 86 & 8.2 & 171 & 16.3 & 134 & 12.8 & 316 & 30.1 & 343 & 32.7 & 1050 & 100.0 \\
\hline $\begin{array}{l}\text { When the teacher continuously raises voice } \\
\text { (screams) during lesson, I find it hard to learn } \\
\text { this subject/module. } \\
\end{array}$ & 89 & 8.5 & 141 & 13.4 & 105 & 10.0 & 260 & 24.8 & 455 & 43.3 & 1050 & 100.0 \\
\hline $\begin{array}{l}\text { When the teacher speaks in quiet and docile } \\
\text { voice, I am prone to be motivated in lessons. }\end{array}$ & 46 & 4.4 & 85 & 8.1 & 114 & 10.9 & 254 & 24.2 & 551 & 52.5 & 1050 & 100.0 \\
\hline $\begin{array}{l}\text { When the teacher always speaks at the same } \\
\text { pace, I lose interest in lessons. }\end{array}$ & 251 & 23.9 & 210 & 20.0 & 191 & 18.2 & 217 & 20.7 & 181 & 17.2 & 1050 & 100.0 \\
\hline
\end{tabular}

\section{Conclusions}

Based on the study and the analysis conducted, we may state that:

Choice of proper words during learning process at school is paid special importance by the students, not only to acquire new knowledge during lessons, but also to be more clear and motivated. The use of slang words by more than half of the students is not regarded as a good option for the more effective meaning of lesson.

Further, it is observed a high trend to assess the para-verbal or pre-linguistic aspects of communication, such as voice pitch, intonation, pace, timbre etc, where especially a prolonged use of the high pitch of voice by the teacher brings 
concerns and difficulties for concentration and lesson comprehension by the students. On the other hand, it is highlighted that soft tones of voice, calm and docile speaking makes the students not only feel more comfortable, but also to be more motivated in lessons.

Further, by comparing male and female students, we generally note differences in the perception of verbal communication between genders and that female students are those dominating with highest academic performance.

\section{References}

Argyle, M. (1977). Bodily communication. New York. International Universities Press.

Austin, J. L. (1962). How to do things with words. Oxford. Oxford University Press.

Bateson, G., J. Ruesch. (1951). Communication: The Social Matrix of Psychiatry. New York. Norton.

Borman, E. G. (1988). Symbolic convergence theory: a communication formulations based on hommo narrens. Journal of Communication, 35: 128-39.

Brekelmans, M., Levy, J., Rodriguez, R. (1993). A typology of teacher communication style. In T. Wubbels., J. Levy, Do you know what you look like? Londra. The Falmer Press.

Butterworth, B. (1978). Maxims for studying conversations, Semiotica, 24, 217-229.

De Saussure, F. (1983). Course in General Linguistics. Chicago. Open Court Classics.

Fiorani, E. (1998). Grammatica della comunicazione Milano. Lupetti.

Hoben, J. B. (1954). English Communication at Colgate Re-examined. Journal of Communication 4: 77.

Jakobson, R. (1966). Saggi di linguistica generale. Milano. Feltrinelli.

Littlejohn, S., Foss, K. (2005). Theories of human communication. Belmont. Thomson-Wadswoth.

Miller, K. (2002). Communication Theories: Perspectives, Processes, and Contexts. Boston. McGraw-Hill.

Patrick, B. C., Hisley, J. \& Kempler, T. (2000). "What's everybody so excited about?" The effects of teacher enthusiasm on student intrinsic motivation and vitality. The Journal of Experimental Education, 68(3), 217-236.

Pearce, W. B. (1989). Communication and the human condition. Carbondale. Southern Illinois University Press.

Peirce, C. S. (1980). Semiotica. I fondamenti della semiotica cognitiva. Torino. Einaudi.

Rosengren, K. E. (2001). Introduzione allo studio della comunicazione. Bolognia. II Mulino.

Searle, J. R. (1979). Speech acts. Cambridge. Cambridge University Press.

Shannon, C., Weaver, W. (1949). The mathematical theory of communication. Urbana. University of Illinois Press,

Watzlawick, P., Beavin, J. H., Jackson, D. D. (2008). Pragmatica della Comunicazione Umana Studio dei Modelli Interattivi Delle Patologie e dei Paradossi. Romë. Astrolabio.

Zimmerman, B. J. (2001). Self-regulated learning and academic achievement theoretical perspectives. In B. J. Zimmerman \& D. H. Schunk, Theories of selfregulated learning and academic achievement: An overview and analysis. Mahwah. Lawrence Erlbaum Associates. 